\title{
ANALISIS PENGARUH ARUS KAS TERHADAP PROFITABILITAS PADA PT MAYORA INDAH TBK
}

\author{
Hendro Sasongko \\ Dosen Tetap Fakultas Ekonomi Universitas Pakuan \\ Dewi Apriani \\ Mahasiswa Fakultas Ekonomi Universitas Pakuan
}

\begin{abstract}
ABSTRAK
Penelitian ini bertujuan untuk mengetahui apakah arus kas baik secara parsial maupun simultan berpengaruh terhadap profitabilitas (ROA) pada PT Mayora Indah Tbk tahun 2010-2014. Penelitian mengenai analisis pengaruh arus kas terhadap profitabilitas. Jenis penelitian ini merupakan penelitian korelasional dengan jumlah sampel sebanyak 10 per enam bulan dalam laporan keuangan pada PT Mayora Indah Tbk selama periode 2010-2014. Proses analisis data yang dilakukan terlebih dahulu adalah uji asumsi klasik dan selanjutnya dilakukan pengujian hipotesis. Metode statistik yang digunakan adalah regresi linier berganda dengan menggunakan SPSS. Hasil penelitian menunjukkan bahwa arus kas yang terdiri dari arus kas operasi, arus kas investasi dan arus kas pendanaan secara simultan tidak terdapat pengaruh yang signifikan terhadap profitabilitas (ROA). Hasil pengujian secara parsial menunjukkan bahwa variabel arus kas operasi, arus kas investasi dan arus kas pendanaan tidak terdapat pengaruh yang signifikan terhadap profitabilitas (ROA).
\end{abstract}

Kata kunci: Arus kas operasi, arus kas investasi, arus kas pendanaan dan profitabilitas (ROA).

\section{ABSTRACT}

This study aims to determine whether the cash flows either partially or simultaneously affect the profitability (ROA) at PT Mayora Indah Tbk 2010-2014. Research on the cash flow analysis of the effect on profitability. This type of research is a correlational study with a total sample of 10 per six months in the financial statements at PT Mayora Indah Tbk during the period 2010-2014. The process of data analysis done first is the classic assumption test before hypothesis test. Statistical method used is multiple linear regression using SPSS. The results showed that cash flow is comprised of operating cash flow, cash flow investing and financing cash flows simultaneously there is no significant effect on profitability (ROA). Partial test results show that the variable operating cash flow, cash flow investing and financing cash flow is not a significant influence on profitability (ROA).

Keywords: operating cash flow, investing cash flows, financing cash flow and profitability (ROA).

\section{Pendahuluan}

Informasi arus kas sangat berguna untuk menentukan kebijakan-kebijakan perusahaan dalam menjalankan kegiatan operasionalnya sedangkan informasi arus kas bagi pihak lain adalah sebagai alternatif analisa dalam pengalokasian profitabilitas. Kas juga mempunyai peranan yang sangat penting dalam kelangsungan aktivitas perusahaan, sehingga dalam pengelolaannya diperlukan perhatian yang khusus. Perusahaan harus memaksimalkan uang kas yang ada tanpa harus membiarkan uang terlalu banyak didalam kas dengan cara membiayai aktivitas operasi, investasi, pendanaan secara efektif dan efisien serta dapat melakukan perluasan usaha.

Arus kas aktifitas operasi melaporkan ringkasan penerimaan dan pembayaran kas dari aktivitas operasi. 
Arus kas aktivitas investasi melaporkan transaksi kas dari pembelian dan penjualan dari asset yang sifatnya permanen (asset tetap). Arus kas aktifitas pendanaan melaporkan transaksi kas yang berhubungan dengan investasi kas oleh pemilik, pinjaman, dan penarikan kas oleh pemilik, apabila penghasilan yang dihasilkan dari kegiatan tersebut meningkat secara terus menerus dan penggunaan aktivanya juga dilakukan secara efektif serta efesien maka dapat menghasilkan laba yang tinggi. Sehingga untuk mengukur atau menghitung profit yang diperoleh perusahaan dalam satu periode tertentu diperlukannya rasio profitabilitas. Cara yang paling umum yang digunakan perusahaan untuk menilai dan mengukur efektivitas penggunaan asset yang digunakan untuk memperoleh laba adalah melalui analisis rasioreturn on assets. Return on assets menunjukan kemampuan perusahaan dalam memanfaatkan assetnya dalam memperoleh laba, seperti yang diungkapkan oleh Dwi Prastowo dan Juliaty Rifka (2005:91), menyatakan “" Return on assets cara untuk mengukur kemampuan perusahaan dalam memanfaatkan assetnya untuk memperoleh laba".

Dengan demikian peranan arus kassangat berpengaruh dalam mengelola kegiatan perusahaan, agar dapat membiayai aktivitas operasi, investasi dan pendanaan perusahaannya. Perusahaan harus mampu mengatur dan memanfaatkan kasnya dengan sebaik mungkin, supaya tidak terjadi ketidakefektifan kas yang dapat menyebabkan laba berkurang.

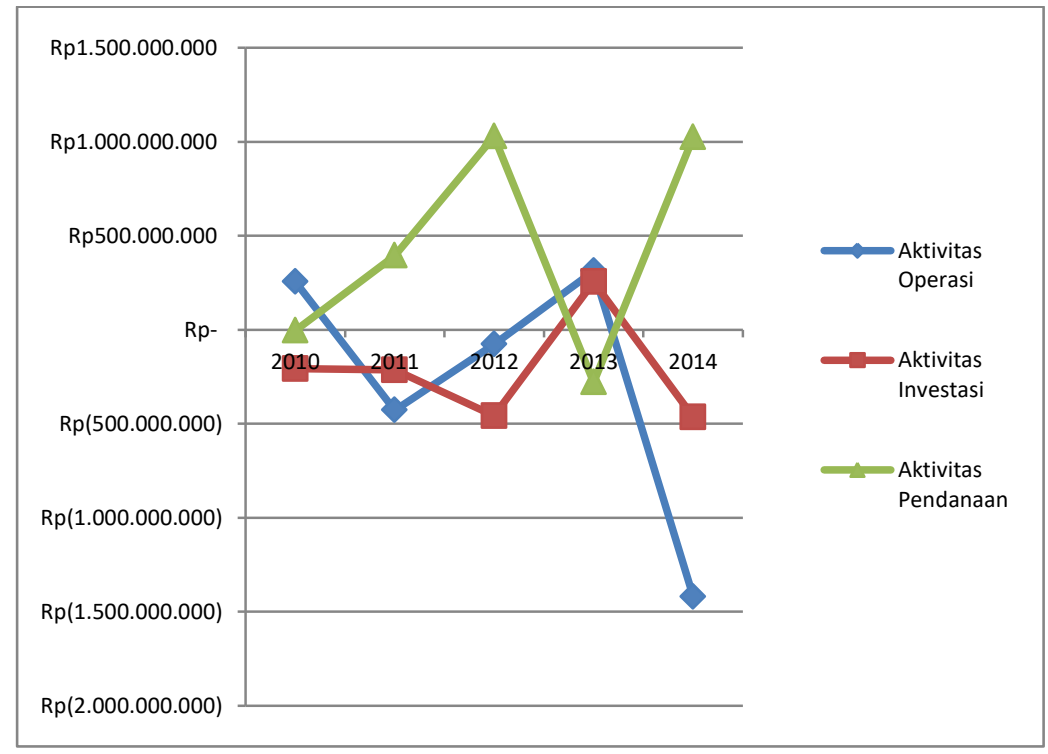

Gambar 1.

Grafik Laporan Arus Kas PT Mayora Indah Tbk Periode 30 Juni 2010-2014 (Dalam ribuan rupiah)

Dari gambar 1, dapat dilihat Laporan arus kas dari arus kas aktivitas operasi, investasi dan pendanaan mengalami naik turun secara fluktuasi. Penurunan yang sangat signifikan dapat dilihat dari arus kas aktivitas operasi pada tahun 2013 ke 2014 terjadi penurunan sebesar Rp1.107.972.016. Penurunan ini diasumsikan akibat peningkatan penjualan tidak terlalu 
signifikan, sedangkan pembayaran kas kepada pemasok, kontraktor dan karyawan sangat besar yang telah jatuh tempo dan juga adanya pengeluaran untuk aset tetap sehingga mengakibatkan arus kas aktivitas operasi turun secara signifikan. Namun hal ini bukan berarti perusahaan mengalami kerugian tetapi perusahaan masih bisa memperoleh laba. Begitu pula pada arus kas dari aktivitas investasi juga terjadi penurunan pada tahun yang sama yaitu pada tahun 2013 ke 2014 sebesar Rp152.563.467. Ini terjadi karena perusahaan melakukan pinjaman untuk investasi kepada anakanak perusahaan yaitu PT Torabika Eka Semesta dan pembuatan produk baru untuk investasi dimasa yang akan datang. Sedangkan arus kas dari aktivitas pendanaan terjadinya peningkatan yang sangat signifikan pada tahun yang sama yaitu 2013 ke 2014 sebesar Rp743.953.440. Diasumsikan akibat terjadinya bank pinjaman jangka pendek dan jangka panjang untuk membiayai biaya perluasan aset tetap atau pembuatan produk baru.

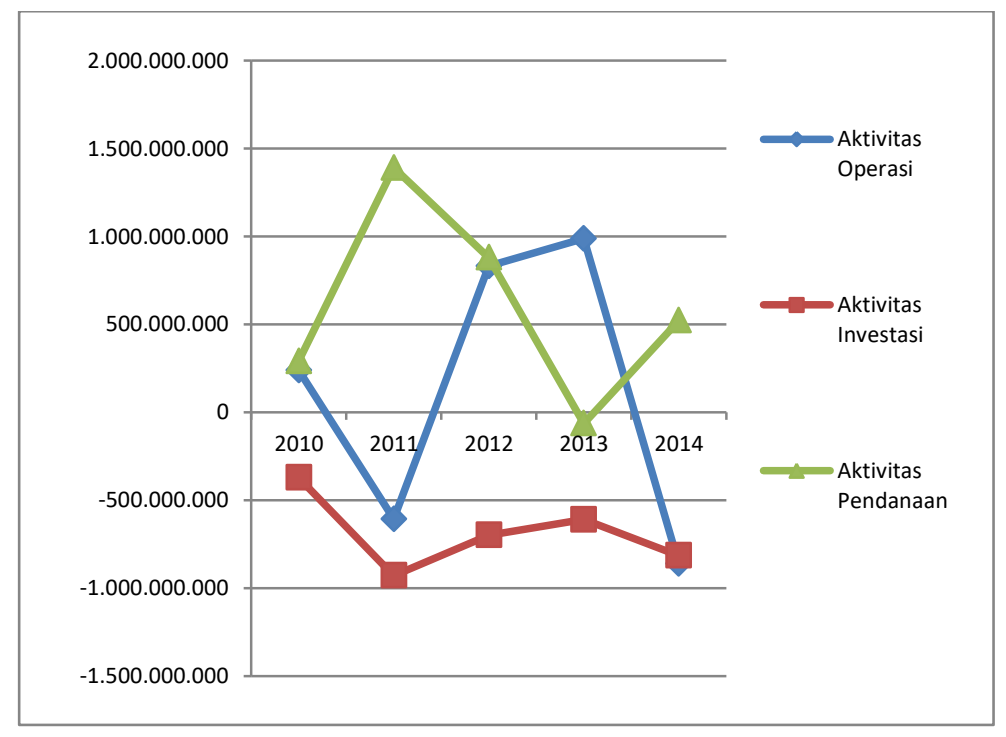

Gambar 2.

Grafik Laporan Arus Kas PT Mayora Indah Tbk Periode 31 Desember 2010-2014 (Dalam ribuan rupiah)

Pada PT. Mayora Indah Tbk, dapat dilihat Laporan Arus Kas dari arus kas aktivitas operasi, investasi dan pendanaan mengalami naik turun secara fluktuasi. Penurunan yang sangat signifikan dapat dilihat dari arus kas aktivitas operasi pada tahun 2010 ke 2011 terjadi penurunan sebesar Rp369.685.600. Penurunan ini diasumsikan akibat peningkatan penjualan tidak terlalu signifikan, sedangkan pembayaran kas kepada pemasok sangat besar yang telah jatuh tempo dan adanya pengeluaran untuk aset tetap. Namun hal ini bukan berarti perusahaan mengalami kerugian tetapi perusahaan masih bisa memperoleh laba. Begitu pula pada arus kas dari aktivitas investasi juga terjadi penurunan pada tahun yang sama yaitu pada tahun 2010 ke 2011 sebesar Rp557.223.778. Ini diasumsikan karena perusahaan melakukan pinjaman untuk investasi kepada anak-anak perusahaan, perluasan 
aset tetap atau pembuatan produk baru untuk investasi dimasa yang akan datang. Arus kas dari aktivitas pendanaan terjadinya peningkatan yang sangat signifikan pada tahun 2010 ke 2011 sebesar Rp1.100.252.410. Diasumsikan akibat terjadinya bank pinjaman jangka pendek dan jangka panjang untuk membiayai biaya perluasan aset tetap atau pembuatan produk baru.

Adapun tujuan dari penelitian ini adalah 1) Untuk mendeskripsikan pelaporan dan perkembangan arus kas pada PT Mayora Indah Tbk Tahun 20102014; 2) Untuk menganalisis pencapaian profitabilitas pada PT Mayora Indah Tbk tahun 2010-2014; dan 3) Untuk menganalisis seberapa besar pengaruh pelaporan arus kas terhadap profitabilitas pada PT Mayora Indah Tbk Tahun 20102014.

\section{Tinjauan Pustaka}

\subsection{Arus Kas}

Menurut Kieso dan Weygandt (2009:247) yang diterjemahkan oleh Emil Salim, "laporan arus kas yaitu laporan yang melaporkan penerimaan kas, pembayaran kas, dan perubahan bersih pada kas yang berasal dari aktivitas operasi, investasi dan pendanaan dari suatu perusahaan selama satu periode dalam suatu format yang merekonsiliasi saldo kas awal dan saldo kas akhir periode".

Menurut PSAK No. 02 (2012), "arus kas adalah arus masuk dan arus keluar kas dan setara kas".

Menurut Sofyan Syafri Harahap (2011:257), “Arus Kas merupakan suatu laporan yang memberikan informasi yang relevan tentang penerimaan dan pengeluaran kas suatu perusahaan pada suatu periode tertentu, dengan mengklasifikasikan transaksi pada kegiatan operasi, investasi, dan pendanaan".
Berdasarkan pengertian diatas dapat disimpulkan laporan arus kas adalah merupakan laporan keuangan yang berisi informasi aliran kas masuk dan aliran kas keluar dari suatu perusahaan selama periode tertentu.

\subsubsection{Tujuan dan Manfaat Laporan Arus Kas \\ Menurut Dwi Prastowo (2014:33)} tujuan laporan arus kas ialah, "Laporan arus kas disusun dengan tujuan untuk memberikan informasi historis mengenai perubahan kas dan setara kas dari suatu perusahaan, dengan mengklasifikasikan arus kas berdasarkan aktivitas operasi, investasi dan pendanaan selama periode akuntansi tertentu. Dengan demikian tujuan laporan arus kas adalahuntuk memberikan kepada pengguna, informasi tentang mengapa posisi kas perusahaan berubah selama periode akuntansi”.

Menurut Kieso dan Weygandt (2009:204) manfaat dari laporan arus kas yang membantu para investor, kreditur, dan pihak lainnya sebagai berikut:

1. Kemampuan entitas untuk menghasilkan arus kas dimasa depan.Tujuan utama dari pelaporan keuangan adalah memberikan informasi yang akan memungkinkan untuk memprediksi jumlah, waktu, dan ke tidakpastian arus kas dimasa depan. Dengan memeriksa hubungan antara pos-pos seperti penjualan dan arus kas bersih dari kegiatan operasi serta kenaikan atau penurunan kas, maka dimungkinkan untuk untuk membuat prediksi yang lebih baik atas jumlah, waktu, dan ketidakpastian arus kas di masa depan, dibandingkan dengan menggunakan data dasar akrual.

2. Kemampuan entitas untuk membayar dividen dan memenuhi kewajiban kas adalah hal yang penting. Jika perusahaan tidak mempunyai kas 
yang cukup, maka gaji karyawan tidak dapat dibayar, hutang tidak dapat dilunasi, dividen tidak dapat dibayar, dan peralatan tidak dapat dibeli. Laporan arus kas menunjukan bagaimana kas digunakan dan dari mana kas itu berasal. Karyawan, kreditor, parapemegang saham memiliki kepentingan dengan laporan ini, karena menunjukan arus kas yang terjadi dalam perusahaan.

3. Penyebab perbedaan antara laba bersih dan arus kas bersih kegiatan operasi. Angka laba bersih merupakan hal yang penting, karena memberikan informasi tentang keberhasilan atau kegagalan sebuah perusahaan bisnis dari suatu periose keperiode lainnya.

4. Transaksi investasi dan pembiayaan yang melibat kas dan non kas selama suatu periode, memeriksa kegiatan investasi perusahaan (pembelian dan penjualan aktiva selain dari produknya) dan kegiatan pembiayaannya (pinjaman dan pelunasan pinjaman, investasi oleh pemilik, dan distribusi kepada pemilik), para pembaca laporan keuangan dapat memahami dengan lebih baik mengapa aktiva dan kewajiban bertambah atau berkurang selama satu periode.

\subsection{Profitabilitas}

Menurut Agus Sartono (2010:122), "profitabilitas adalah kemampuan perusahaan memperoleh laba dalam hubungannya dengan penjualan, total aktiva maupun modal sendiri".

Menurut Van Horne dan Machwowicz (2005:145) "Profitability ratios is ratios that relate profits to sales and investment". Artinya bahwa profitabilitas adalah rasio yang memperlihatkan keuntungan yang diperoleh atas penjualan saham dan kegiatan investasi perusahaan.
Menurut Dewi Astuti (2005:152), "profitabilitas berasal dari kata profit dan ability. Didalam kontak bisnis profitberarti pendapatan yang diterima dari suatu kegiatan bisnis setelah dikurangi biaya-biaya yang relevan. Sedangkan ability berarti suatu kemampuan perusahaan untuk melakukan sesuatu".

Jadi dapat disimpulkan profitabilitas merupakan suatu bentuk rasio yang digunakan untuk mengetahui sejauh mana perusahaan tersebut menjalankan aktivitas untuk memperoleh keuntungan dari tingkat penjualan, jumlah asset dan modal sendiri.

\subsection{Jenis-jenis Rasio Profitabilitas 1. Return on Asset (ROA)}

Menurut Lestari dan Toto Sugiharto (2007:196) Return On Assets (ROA) adalah rasio yang digunakan untuk mengukur keuntungan bersih yang diperoleh dari penggunaan aktiva. Dengan kata lain, semakin tinggi rasio ini maka semakin baik produktivitas aset dalam memperoleh keuntungan bersih, hal ini selanjutnya akan meningkatkan daya tarik perusahaan kepada investor. Rasio ini dihitung dengan formula yaitu:

$$
R O A=\frac{\text { Laba bersih }}{\text { Total Aset }} \times 100 \%
$$

\section{Return On Equity (ROE)}

Menurut Agus Sartono (2010:124), "ROE ialah untuk mengukur kemampuan perusahaan memperoleh laba yang tersedia bagi pemegang saham perusahaan. Rasio ini juga dipengaruhi dengan besar kecilnya hutang perusahaan apabila proporsi hutang semakin besar maka rasio ini juga akan semakin besar". Rasio ini dihitung dengan formula yaitu: 


$$
R O E=\frac{\text { Laba bersih }}{\text { Total Ekuitas }} \times 100 \%
$$

\section{Gross Profit Margin (GPM)}

Menurut Kasmir (2008:200), "margin laba kotor menunjukan laba yang relatif terhadap perusahaan, dengan cara penjualan bersih dikurangi harga pokok penjualan. Rasio ini merupakan cara untuk penetapan harga pokok penjualan". Rasio ini dihitung dengan formula yaitu:

$$
G P M=\frac{\text { Penjualan }-H P P}{\text { Penjualan }} \times 100 \%
$$

\section{Net Profit Margin (NPM)}

Menurut Kasmir (2008:200), "margin laba bersih merupakan ukuran keuntungan dengan membandingkan antara laba bersih setelah bunga dan pajak dibandingkan dengan penjualan. Rasio ini menunjukan pendapatan bersih prusahaan atas penjualan". Rasio ini dihitung dengan formula yaitu:

$$
N P M=\frac{\text { Laba bersih }}{\text { Penjualan }} \times 100 \%
$$

\section{Metodologi Penelitian}

\subsection{Jenis Penelitian}

Jenis atau bentuk penelitian yang digunakan adalah penelitian kuantitatif berupa hubungan kolerasional antara Arus kas terhadap Profitabilitas (return on assets) pada PT. Mayora Indah Tbk periode 2010-2014.

\subsection{Unit Analisis dan Jenis Data}

Unit analisis yang digunakan dalam penelitian ini berupa Organization. Jenis data yang diperlukan untuk mendukung penelitian ini merupakan jenis data kuantitatif yang merupakan data sekunder berupa laporan keuangan (annually report) PT. Mayora Indah, Tbk lima periode yaitu tahun 2010-2014 dan diperoleh melalui situs homepage Bursa Efek Indonesia (BEI) yaitu www.idx.co.id.

Tabel 1.

Oprasionalisasi Variabel

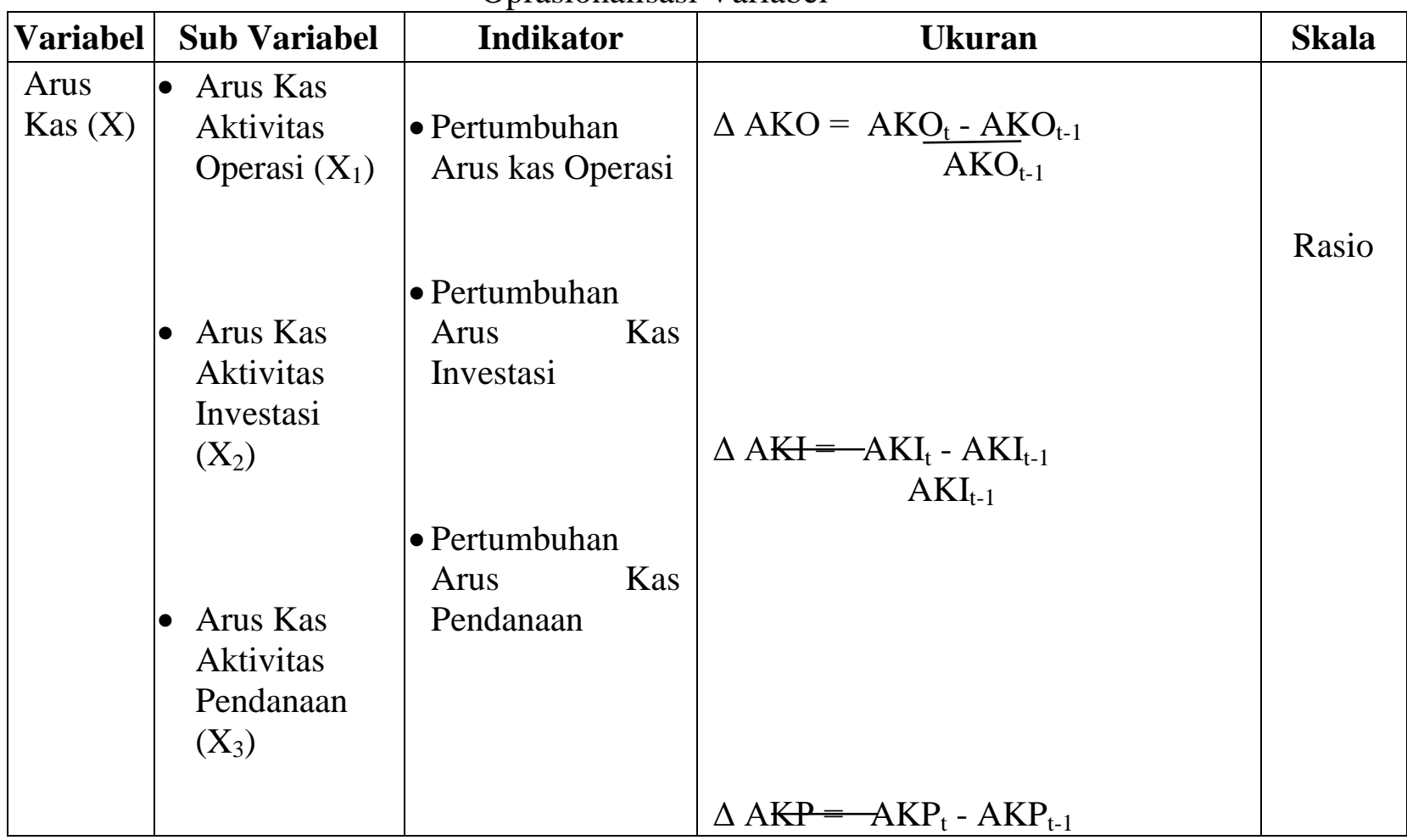




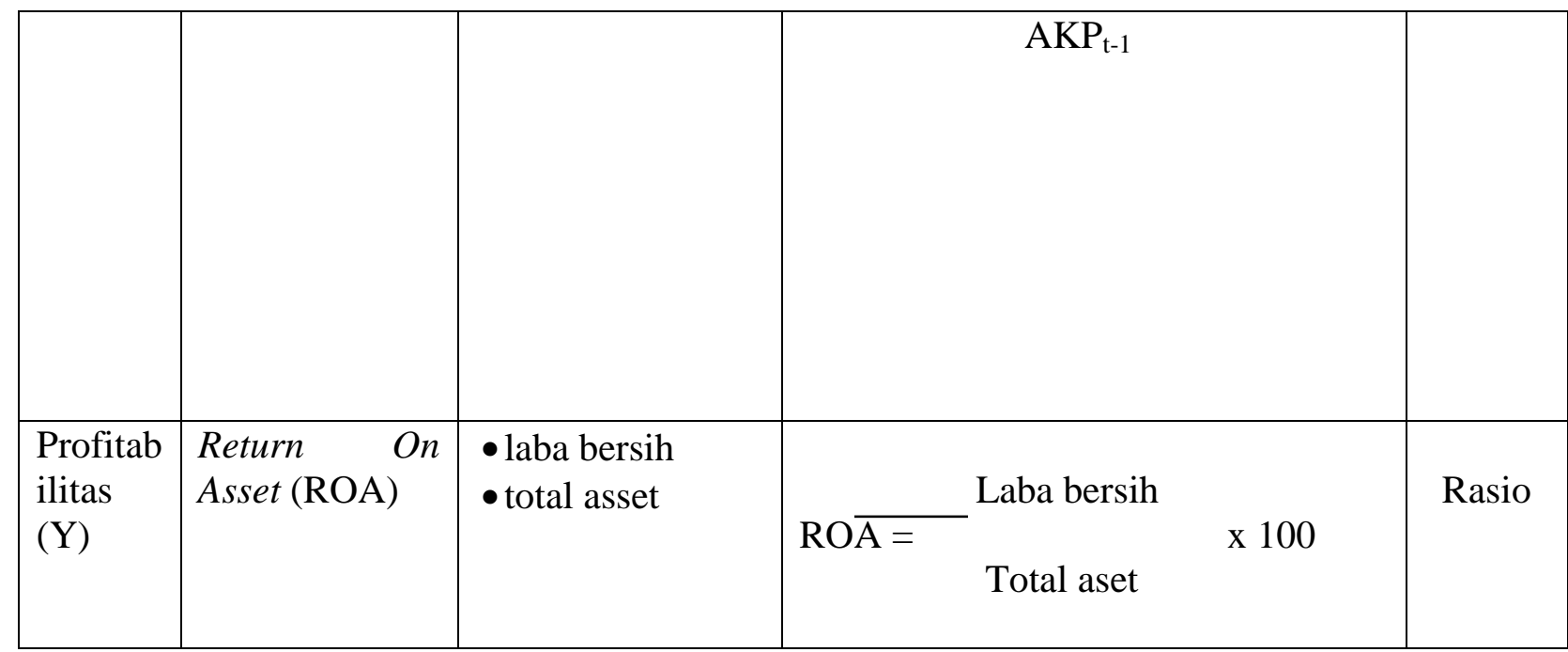

\subsection{Metode Penarikan Sampel}

Dalam penelitian Analisis Pengaruh Arus Kas Terhadap Profitabilitas pada PT Mayora Indah Tbk Periode 2010-2014, peneliti tidak menggunakan metode penarikan sampel dikarenakan peneliti hanya meneliti satu perusahaan saja.

\subsection{Metode Analisis}

Metode analisis yang digunakan dalam penelitian ini adalah Deskriptif Statistik yang berfungsi sebagai penganalisis data dengan menggambarkan sampel data yang telah dikumpulkan tanpa penggeneralisasian. Penelitian ini menjabarkan jumlah data, rata-rata, nilai minimum dan maksimum serta standar deviasi. Penulis mengolah data dengan menggunakan SPSS 20 (Statistical Product and Service Solution) dengan analisis regresi linier berganda.

\section{PEMBAHASAN}

Pelaporan arus kas PT Mayora Indah Tbk menggunakan metode langsung, arus kas PT Mayora Indah Tbk mengalami naik turun secara fluktuatif baik dilihat dari arus kas operasi, investasi dan pendanaan. Kondisi ini disimpulkan bahwa, perusahaan mengalami pasang surut dalam persaingan dunia bisnis baik dengan sesama jenis produksi maupun tidak, walaupun begitu perusahaan tetap melaporkan laporan arus kas sesuai dengan prinsip akuntansi yang berlaku umum.

Berdasarkan pengolahan data secara deskriptif mengenai arus kas (arus kas operasi, investasi, dan pendanaan) dan profitabilitas (ROA) didapat hasil sebagai berikut :

1. Rata-rata arus kas operasi PT Mayora Indah Tbk pada tahun 2011 ke 2012 hingga 2013 terlihat mengalami kenaikan yang tidak terlalu tinggi. AKO yang semakin tinggi menunjukkan bahwa penerimaan pelanggan meningkat diakibatkan penjualan semakin besar, semakin besar AKO akan semakin menguntungkan karena akan semakin kecil risiko yang ditanggung atas kegagalan yang mungkin terjadi di perusahaan seperti piutang blm dibayar yang telah jatuh tempo serta belum banyaknya barang yang terjual. Pada tahun 2011 dan 2014 AKO mengalami penurunan, dengan semakin kecil AKO maka laba yang dihasilkan perusahaan juga kecil. 


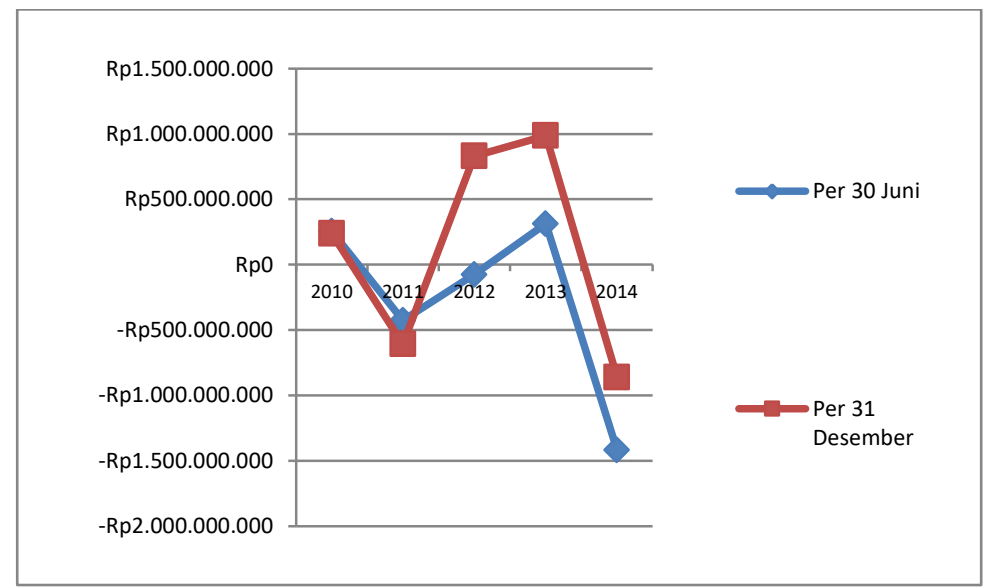

Gambar 3.

Grafik Arus Kas Operasi Tahun 2010-2014

Pada grafik terlihat dengan jelas bahwa arus kas akativitas operasi mengalami peningkatan yang sangat tinggi per 31 Desember pada tahun 2011 ke 2012 yaitu meningkat sebesar Rp222.304.511. dibandingkan dengan per 30 Juni. Hal tersebut dikarenakan pendapatan yang diterima oleh PT Mayora Indah Tbk mengalami peningkatan yang dihasilkan dari penerimaan pelanggan serta adanya penerimaan restitusi pajak, sedangkan pembayaran kepada pemasok tidak terlalu besar.
2. Rata-rata arus kas investasi PT Mayora Indah Tbk pada tahun 2011, 2012 per 30 Juni dan 2014 mengalami penurunan. Pada tahun 2012 per 31 Desember dan 2013 AKI mengalami kenaikan. Arus kas investasi yang semakin tinggi menunjukkan bahwa perusahaan melakukan penjualan atas aset tetap serta perusahaan melakukan investasi kepada anak perusahaan.

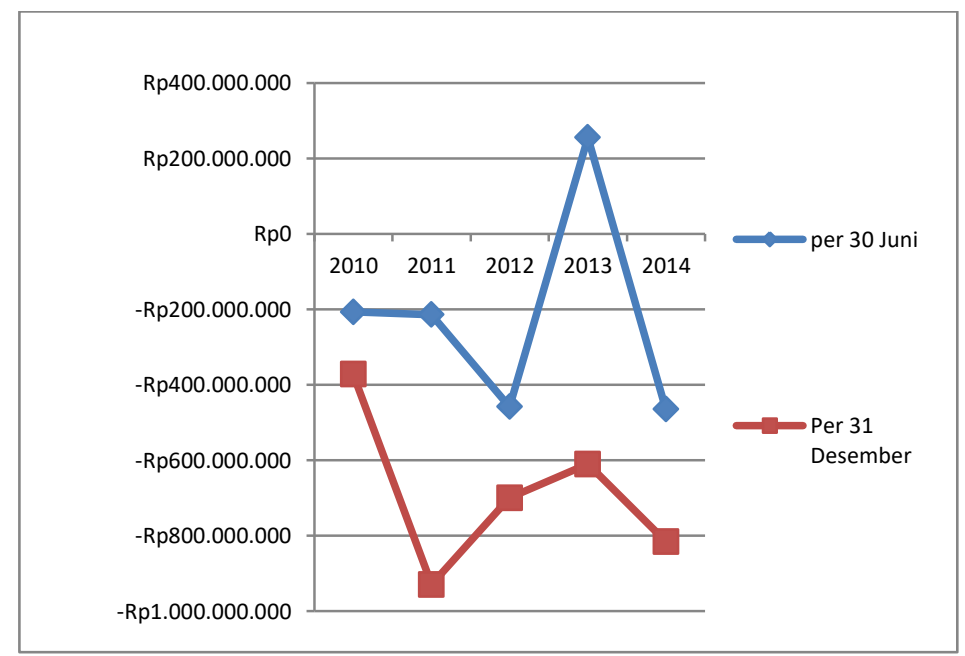

Gambar 4.

Grafik Arus Kas Investasi Tahun 2010-2014

Pada grafik terlihat dengan jelas bahwa arus kas aktivitas investasi pada PT
Mayora Indah Tbk cenderung fluktuatif. Adapun penjelasan hasil penelitian 
variabel X2 (Arus Kas) adalah sebagai berikut:

a. Pada tahun 2010-2012 arus kas investasi per 30 Juni mengalami penurunan, sedangkan per 31 Desember mengalami penurunan penurunan yang sangat signifikan hanya pada tahun 2010 ke 2011 sebesar Rp-555.223.778. Ini terjadi dikarenakan perusahaan melakukan pinjaman untuk investasi kepada anak-anak perusahaan yaitu kepada PT Torabika Eka Semesta dan pembuatan produk baru untuk investasi dimasa yang akan datang.

b. Pada tahun 2012-2013 arus kas investasi per 30 Juni dan 31 Desember mengalami kenaikan, tetapi kenaikan yang sangat signifikan terjadi pada 30 juni tahun 2013 sebesar Rp255.445.452. Ini terjdi dikarenakan perusahaan melakukan penjualan atas aset tetap serta adanya penerimaan bunga.

c. Pada tahun 2013-2014 arus kas investasi per 30 Juni dan 31 Desember mengalami penurunan kembali, tetapi penurunan yang sangat signifikan terjadi per 30 Juni 2014 sebesar Rp-464.740.418. Ini terjadi karenakan perolehan aset tetap berkurang dan perusahaan melakukan pinjaman untuk investasi kepada anak-anak perusahaan yaitu kepada PT Torabika Eka Semesta.

3. Rata-rata arus kas pendanaan PT Mayora Indah Tbk pada tahun 2011, 2012 dan 2014 mengalami kenaikan. Pada tahun 2013 AKP mengalami penurunan. Nilai arus kas pendanaan yang tinggi, menunjukkan karena adanya pinjaman jangka pendek maupun jangka panjang untuk membiayai perluasan aset tetap tetapi pada tahun 2012 per 30 Juni perusahaan melakukan pinjaman tersebut bukan untuk investasi melainkan untuk kegiatan operasional perusahaan yang mengakibatkan kegiatan investasi menurun. Dengan arus kas pendanaan meningkat maka laba yang dihasilkan akan menurun.

(dalam ribuan rupiah)

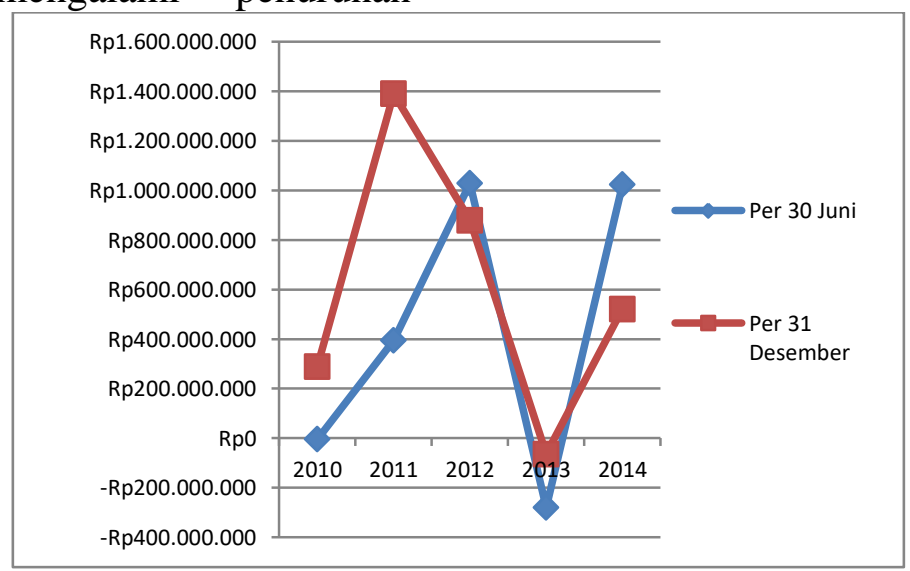

Gambar 5.

Grafik Arus Kas Pendanaan Tahun 2010-2014

Pada grafik terlihat dengan jelas bahwa arus kas aktivitas pendanaan pada PT Mayora Indah Tbk cenderung fluktuatif. Adapun penjelasan hasil penelitian variabel $\mathrm{X}_{3}$ (arus kas pendanaan) adalah sebagai berikut:

a. Pada tahun 2010 per 30 Juni dan 31 Desember PT Mayora Indah Tbk memiliki arus kas pendanaan sebesar Rp-4.000.000 dan Rp289.798.337.

b. Pada tahun 2011 ke 2012 per 30 Juni mengalami peningkatan sebesar Rp394.853.333 ke Rp634.232.471 dari tahun sebelumnya, sedangkan per 31 Desember meningkat secara signifikan tetapi hanya pada tahun 
2011 sebesar Rp1.100.252.410, ini terjadi dikarenakan adanya pinjaman jangka pendek maupun jangka panjang untuk membiayai perluasan aset tetap atau inovasi produk baru.

c. Pada tahun 2013 per 30 Juni mengalami penurunan secara signifikan sebesar Rp749.178.745 dari tahun sebelumya, sedangkan per 31 Desember terjadi penurunan pada tahun 2012 dan 2013 tetapi penurunan yang paling signifikan terjadi pada tahun 2013 sebesar Rp815.809.488 dari tahun sebelumnya. Ini terjadi dikarenakan adanya pembayaran utang jangka pendek yang terlalu besar sedangkan pendapatan dari penerimaan pelanggan tidak besar serta adanya penurunan kas dan setara kas pada tahun ini. d. Pada tahun 2014 per 30 Juni dan per 31 Desember sebesar Rp743.953.440 dan Rp458.052.235 Dapat dilihat dari grafik tersebut arus kas pendanaan mengalami kenaikan yang sangat signifikan dari tahun sebelumnya. Ini terjadi dikarenakan jumlah kas dan setara kas mulai kembali positif dengan kata lain mengalami kenaikan kembali.

4. Rata-rata return on asset (ROA) PT Mayora pada tahun 2011 dan 2014 ROA mengalami penurunan. Tahun 2010, 2012, dan 2013 mengalami kenaikan. Nilai ROA yang tinggi, menunjukan adanya jumlah penjualan dan pendapatan, jumlah beban operasional dengan kata lain peningkatan penjulan harus lebih besar daripada peningkatan biaya operasional.

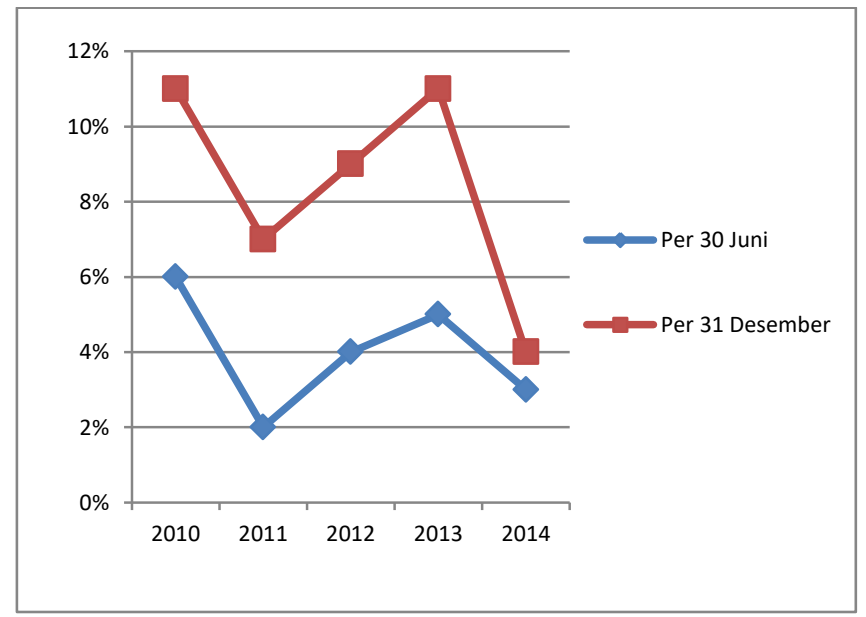

Gambar 6.

Grafik: Return On Asset (ROA) Tahun 2010-2014

Pada grafik terlihat dengan jelas bahwa return on asset (ROA) pada PT Mayora Indah Tbk cenderung fluktuatif. Adapun penjelasan hasil penelitian variabel X2 (arus kas investasi) adalah sebagai berikut:

1. Pada tahun 2010 per 30 Juni dan 31 Desember PT Mayora Indah Tbk memiliki return on assets sebesar $6 \%$ dan $11 \%$.
2. Pada tahun 2011 per 30 Juni dan 31 Desember profitabilitas (Return On Asset) PT Mayora Indah Tbk mengalami penurunan sebesar $2 \%$ dan $7 \%$ dari tahun sebelumnya, hal ini disebabkan adanya penambahan biaya operasi sampai tingkat tertentu dengan harapan adanya kenaikan penjualan sehingga penerimaan dari jumlah penjualan dan pendapatan, jumlah harga pokok penjualan dan 
pendapatan, jumlah beban operasi mengalami kenaikan yang diikiuti dengan total asset yang semakin tinggi.

3. Pada tahun 2012-2013 Profitabilitas (Return On Asset) PT Mayora Indah Tbk mengalami kenaikan sebesar $4 \%$ per 30 Juni tahun 2012 dan 5\% per 30 juni tahun 2013. Sedangkan $9 \%$ per 31 Desember tahun 2012 dan $11 \%$ per 31 Desember tahun 2013. Hal ini disebabkan adanya kenaikan jumlah penjualan dan pendapatan, jumlah harga pokok penjualan dan pendapatan, jumlah beban operasional dengan kata lain peningkatan penjualan harus lebih besar dari pada peningkatan biaya operasional.

4. Pada tahun 2014 per 30 Juni dan 31 Desember Profitabilitas (Return On Asset) PT Mayora Indah Tbk mengalami penurunan kembali yang hanya sebesar 3\% dan $8 \%$ dari tahun sebelumnya.

Pengujian variabel arus kas dan profitabilitas (ROA) semua datanya normal dan tidak terjadi multikolinearitas, karena nilai tolerance berada di atas 0,10 dan nilai VIF berada di bawah 10. Multikolinearitas dimaksudkan untuk menguji adanya hubungan yang kuat di antara beberapa atau semua variabel independen dalam model regresi. Pengujian heteroskedastisitas menggunakan scatterplot model yang melalui diagram pencar dan spearman's rho. Hasil yang diperoleh adalah bahwa tidak terjadi gejala heteroskedastisitas. Pengujian autokorelasi dengan model runs test menunjukkan nilai sebesar 0,737 . Hasil yang diperoleh adalah tidak terjadi autokorelasi karena Asymp. Sig. (2tailed) $0,737>0,05$.

Berdasarkan hasil pengolahan data dengan menggunakan software SPSS 20.0 diperoleh nilai uji $\mathrm{F}$ sebesar 1,668 dengan sig-F sebesar 0,272 (lihat Tabel
16). Hasil yang didapat adalah nilai sig-F tersebut lebih besar dari derajat signifikan 5\% $(\alpha=0,05)$ sehingga dapat disimpulkan bahwa variabel independen (arus kas) secara bersama-sama (simultan) tidak terdapat pengaruh yang signifikan terhadap variabel dependen (return on asset). Hal ini terjadi dikarenakan pengelolaan arus kas operasi, arus kas investasi dan arus kas pendanaan yang kurang optimal seperti masih banyaknya piutang yang belum tertagih dan piutang yang telah jatuh tempo sehingga PT Mayora Indah Tbk melakukan pinjam bank jangka pendek dan pinjaman jangka panjang untuk menambah modal dalam menjalankan dan melanjutkan kegiatan operasional perusahaan atau perusahaan maelakukan investasi.

Dari hasil pengujian hipotesis secara simultan diketahui bahwa arus kas tidak terdapat pengaruh yang signifikan secara bersama-sama terhadap profitabilitas (ROA) pada PT Mayora Indah Tbk tahun 2010-2014. Hasil penelitian ini tidak sesuai dengan hipotesis yang dikemukakan oleh penulis bahwa arus kas mempunyai pengaruh terhadap profitabilitas pada PT Mayora Indah Tbk.

Penelitian terdahulu dilakukan oleh Gunawan Arisdianto (2014), menyimpulkan bahwa arus kas secara simultan tidak berpengaruh secara signifikan terhadap profitabilitas pada PT Fajar Surya Wisesa Tbk. Hasil uji ANOVA ini menjawab hipotesis penelitian yang menyatakan bahwa arus kas tidak ada pengaruh secara signifikan terhadap profitabilitas. Hasil hipotesis ini sesuai dengan hasil hipotesis penelitian terdahulu Gunawan Arisdianto (2014) yang dilakukan di PT. Fajar Surya Wisesa Tbk.

Pengujian secara parsial arus kas operasi, arus kas investasi dan arus kas pendanaan tidak terdapat pengaruh yang 
signifikan terhadap profitailitas (ROA), arus kas operasi ditunjukkan dengan nilai sig-t sebesar 0,232 yang lebih besar $5 \% \quad(\alpha=0,05)$, arus kas investasi ditunjukkan dengan nilai sig-t sebesar 0,948 yang lebih besar $5 \%(\alpha=0,05)$ dan arus kas pendanaan ditunjukkan dengan nilai sig-t sebesar 0,203 yang lebih besar 5\% $(\alpha=0,05)$ (lihat tabel 12).

Hasil penelitian ini terbukti arus kas operasi, arus kas investasi dan arus kas pendanaan tidak terdapat pengaruh yang signifikan terhadap profitabilitas (ROA) pada PT Mayora Indah Tbk, arus kas operasi ditunjukan dengan nilai sig-t 0,232 yang lebih besar $5 \%(\alpha=0,05)$, arus kas investasi ditunjukkan dengan nilai sig-t sebesar 0.948 yang lebih besar $5 \%(\alpha=0,05)$ dan arus kas pendanaan ditunjukkan dengan nilai sig-t sebesar 0,203 yang lebih besar 5\% $(\alpha=0,05)$. Hal ini terjadi dikarenakan walapun penjualan pada PT Mayora Indah Tbk setiap tahunnya meningka, sedangkan tagihan yang dikirim ke pelanggan itu mempunyai jatuh temponya jadi penerimaan kas yang diterima pada PT Mayora Indah Tbk sebagian besar dari piutang yamg telah jatuh tempo, penerimaan tersebut adalah penjualan dari tahun lalu dan sebagian lagi dari tahun yang bersangkutan. Dan juga PT Mayora melakukan pembelian aset tetap yang akan mengurangi kas perusahaan, Sehingga penerimaan kas pada PT Mayora Indah Tbk kurang optimal.

\section{Penutup}

\subsection{Simpulan}

1. Pelaporan arus kas PT Mayora Indah Tbk menggunakan metode langsung, arus kas PT Mayora Indah Tbk mengalami naik turun secara fluktuatif baik dilihat dari arus kas operasi, investasi dan pendanaan. Kondisi ini disimpulkan bahwa, perusahaan mengalami pasang surut dalam persaingan dunia bisnis baik dengan sesama jenis produksi maupun tidak, walaupun begitu perusahaan tetap melaporkan laporan arus kas sesuai dengan prinsip akuntansi yang berlaku umum. Dilihat dari perkembangan arus kas operasi cenderung fluktuatif dengan trend naik ini terjadi dikarenakan pendapatan yang diterima oleh PT Mayora Indah Tbk mengalami peningkatan yang dihasilkan dari penerimaan pelanggan serta adanya penerimaan restitusi pajak, sedangkan pembayaran kepada pemasok tidak terlalu besar. Arus kas investasi cenderung fluktuatif dengan trend menurun hal ini terjadi dikarenakan perusahaan melakukan pembelian aset tetap yang akan mengurangi kas perusahaan. Arus kas pendanaan cenderung fluktuatif dengan trend naik hal ini terjadi dikarenakan PT Mayora Indah Tbk melakukan pinjaman jangka pendek dan jangka panjang yang mencerminkan dalam per enam bulan akuntansi PT Mayora Indah Tbk cenderung tidak dapat memenuhi kewajiban untuk memenuhi biaya operasional atau perusahaan melakukan investasi.

2. Return on asset (ROA) pada PT Mayora Indah Tbk cenderung meningkat selama periode tahun 2010-2014 dengan rata-rata pertumbuhan dari $4 \%$ per 30 Juni menjadi $8 \%$ per 31 Desember setiap enam bulannya. Kondisi demikian mencerminkan bahwa dalam enam bulan periode akuntansi PT Mayora Indah Tbk mengalami kenaikan jumlah penjualan dan pendapatan, jumlah harga pokok penjualan dan pendapatan, jumlah beban operasional dengan kata lain peningkatan penjulan harus lebih besar dari pada peningkatan biaya operasional. 
3. Hasil penelitian ini secara parsial hanya arus kas operasi, arus kas investasi dan arus kas pendanaan tidak terdapat pengaruh yang signifikan terhadap profitabilitas (ROA), karena arus kas operasi ditunjukkan dengan nilai sig-t sebesar 0,232 yang lebih besar $5 \%(\alpha=0,05)$, arus kas investasi ditunjukkan dengan nilai sig-t sebesar 0,948 yang lebih besar 5\% $(\alpha=0,05)$ dan arus kas pendanaan ditunjukkan dengan nilai sig-t sebesar 0,203 yang lebih besar $5 \%(\alpha=0,05)$. Hal ini terjadi dikarenakan walapun penjualan pada PT Mayora Indah Tbk setiap tahunnya meningka, sedangkan tagihan yang dikirim ke pelanggan itu mempunyai jatuh temponya jadi penerimaan kas yang diterima pada PT Mayora Indah Tbk sebagian besar dari piutang yamg telah jatuh tempo, penerimaan tersebut adalah penjualan dari tahun lalu dan sebagian lagi dari tahun yang bersangkutan. Dan juga PT Mayora melakukan pembelian aset tetap yang akan mengurangi kas perusahaan, Sehingga penerimaan kas pada PT Mayora Indah Tbk kurang optimal.

4. Hasil penelitian ini secara bersamasama (simultan) bahwa arus kas tidak terdapat pengaruh yang signifikan terhadap variabel dependen (ROA), diperoleh nilai uji $\mathrm{F}$ sebesar 1,668 dengan sig-F sebesar 0,272 yang lebih besar dari $5 \%(\alpha=0,05)$. Hal ini terjadi dikarenakan pengelolaan arus kas operasi, arus kas investasi dan arus kas pendanaan yang kurang optimal seperti masih banyaknya piutang yang belum tertagih dan piutang yang telah jatuh tempo sehingga PT Mayora Indah Tbk melakukan pinjam bank jangka pendek dan pinjaman jangka panjang untuk menambah modal dalam menjalankan dan melanjutkan kegiatan operasional perusahaan atau perusahaan maelakukan investasi.

\subsection{Saran}

Berdasarkan kesimpulan diatas, maka penulis dapat mengemukakan beberapa hal yang diharapkan dapat dijadikan bahan pertimbangan dan perbaikan dalam penggunaan arus kas terhadap profitabilitas pada PT Mayora Indah Tbk Direktorat Administrasi dan Keuangan untuk masa yang akan datang dan untuk memberikan kontribusi dalam pengembangan ilmu pengetahuan di bidang ekonomi akuntansi pada umumnya dan khususnya mengenai akuntansi keuangan. Adapun saran-saran yang dimaksud adalah sebagai berikut:

1. Bagi perusahaan

a. Walaupun kondisi arus kas yang masih fluktuatif, namun PT Mayora Indah Tbk harus memperhatikan upaya dan strategi yang dapat meningkatkan minat masyarakat (investor) untuk menanamkan modal pada PT Mayora Indah Tbk karena arus kas merupakan sumber informasi bagi para investor untuk menilai kemampuan perusahaan dalam mengalokasikan dana kasnya. Seperti dengan inovasi produk baru, mengurangi piutang yang tak tertagih serta piutang jatuh tempo dan meningkatkan strategi penjualan sehingga memungkinkan laba yang dihasilkan akan lebih tinggi dengan begitu akan menarik minat investor untuk menamkan modalnya di PT Mayora Indah Tbk.

b. perusahaan seharusnya memiliki kiat khusus apabila perusahaan mengalami penurunan dalam kegiatan usahanya akibat Persaingan dengan perusahaan sejenis harus disiasati agar perusahaan tetap bertahan dengan 
usahanya dengan memaksimalkan potensi yang dimiliki perusahaan.

2. Bagi peneliti selanjutnya

a. Bagi penelitian selanjutnya, variabel bebas yang digunakan hendaknya tidak hanya arus kas saja karena masih banyak faktorfaktor lain pada perusahaan yang dapat mempengaruhi profitabilitas seperti modal kerja biaya opersional.

b. Bagi peneliti selanjutnya disarankan menggunakan sampel yang lebih banyak dengan karakteristik yang lebih beragam dari berbagai sektor dan memperpanjang periode penelitian.

\section{DAFTAR PUSTAKA}

Buku

Agus Sartono. 2010. Manajemen Keuangan Teori dan Aplikasi. Yogyakarta: BFE.

Brigham dan Houston. 2010. Dasar-dasr Manajemen Keuangan, Buku Satu (edisi Sebelas). Jakarta: Selemba Empat.

David Sukardi dan Kurniawan Indonajaya. 2010. Manajemen Investasi Pendekatan Tekhnikal dan Fundamental untuk Analisis Saham (Edisi 1). Yogyakarta: Graha Ilmu.

Dewi Astuti. 2005. Manajemen Keuangan Perusahaan. Jakarta: Ghalia Indonesia.

Dwi Prastowo dan Juliaty Rifka. 2005. Analisis Laporan Keuangan: Konsep dan Aplikasi. Yogyakarta: UPP STIM YKPN.

Dwi Prastowo. 2014. Analisis Laporan Keuangan, Edisi Ketiga. Yogyakarta : Unit Penerbit dan Pencetakan.

Farah Margaretha. 2011. Manajemen Keuangan untuk Manajer Non Keuangan. Jakarta: Erlangga.
H. Greuning. 2005. Standar Pelaporan Keuangan Internasional. Jakarta: Salemba Empat.

Imam Ghozali. 2006. Aplikasi Analisis Multivariate Dengan Program SPSS. Badan Penerbit Undio: Semarang.

Jhon J. Wild. 2005. Analisis Laporan Keuangan, Edisi Delapan. Jakarta: Selemba Empat.

Kamaludin dan Indriani. 2012. Manajemen Keuangan. Edisi Revisi. Bandung : CV. Mandar Maju.

Kasmir. 2008. Analisis Laporan Keuangan. Jakarta: Rajawali.

Kasmir. 2011. Analisis Laporan Keuangan. Jakarta: PT Raja Grafindo.

Kiesso Donal E. 2008. Akuntansi Intermediate, Edisi ke Dua Belas Jilid 1. Jakarta: Erlangga.

Kiesso Donald E dan Jerry J. Weygandt. 2009. Akuntansi Intermediate, Jilid Tiga. Jakarta: Erlangga.

Lukman Syamsudin. 2009. Manajemen Keuangan Perusahaan. Jakarta: Raja Grafindo Persada.

Mamduh M Hanafi Dan Abdul Halim. 2002. Analisis Laporan Keuangan. Yogyakarta: UPP AMP YKPN.

Mamduh M Hanafi. 2005. Analisis laporan Keuangan. Yogyakarta: Unit Penerbit dan Percetakan AMP YKPN.

Martono dan Agus Harjito. 2010. Manajemen Keuangan Edisi Tiga. Yogyakarta: Ekonisia.

Pernyataan Standar Akuntansi Keuangan (PSAK). Tahun 2012 No.02.

Singgih Santoso. 2001. SPSS Versi 10: Mengelola Data Statistik Secara Profesional. Jakarta: PT Elex Media Komputindo.

Sofyan Syafri Harahap. 2001. Analitis Kritiss Atas Laporan Keuangan, Cetakan Ketiga. Jakarta: PT Rajagrafindo Persada. 
Sofyan Syafri Harahap. 2011. Analisis Kritis Atas Laporan Keuangan, Jakarta: PT. Raja Grafindo Persada.

Sugiyono. 2012. Metode Penelitian Kombinasi. Bandung: Alfabeta.

Susan Irawati. 2006. Manajemen Keuangan. Bandung: Pustaka.

Van Horne, James C. dan John M. Wachowicz, Jr, 2005. PrinsipprinsipManajemen Keuangan, Buku Satu, Edisi Kedua Belas. Jakarta: Salemba Empat.

\section{Jurnal/Penelitian Berkala}

Dian Pratiwi. 2011. Analisis Biaya Operasional Dan Arus Kas Terhadap Profitabilitas Pada PT Pindad (persero) Bandung. Fakultas Ekonomi Jurusan Akuntansi. Universitas Komputer Indonesia.

Erni Nuraeni. 2011. Pengaruh Arus Kas Dan Modal Kerja Terhadap Profitabilitas PT Metrodata Electronics Tbk. Fakultas Ekonomi Jurusan Akuntansi. Universitas Komputer Indonesia.

Gunawa Arisdianto. Pengaruh Perubahan Arus Kas Terhadap Tingkat Profitabilitas PT Fajar Surya Wisesa Tbk. Sekolah Tinggi Ilmu Ekonomi Indonesia (STIESA) Surabaya.

Lestari, Maharani Ika dan Toto Sugiharto. 2007. Kinerja Bank Devisa dan Bank Non Devisa Dan Faktor-faktor Yang Mempengaruhinya. Procedding PESAT (Psikologi, Ekonomi, Sastra, Arsitek dan Sipil). 1-22 Agustus. Vol.2, Fakultas Ekonomi, Universitas Gunadarma.

Naufal Ubaidillah. 2014. Pengaruh Arus

Kas dan piutang Terhadap Tingkat

Profitabilitas pada Perusahan

Manufaktur Sektor Industri

Barang Konsumsi Sub Sektor
Farmasi yang Terdaftar di Bursa Efek Indonesia. Fakultas Ekonomi Jurusan Akuntansi. Universitas Widyatama.

Oktavianus. 2015. Analisis laporan arus kas dalam menilai kinerja keuangan pada PTP Nusantara IV (persero) unit Kebun Tanah itam Ulu. Fakultas Ekonomi Jurusan Akuntansi. Universitas Katolik Santo Thomas, Medan.

\section{Website}

http//:www.idx.co.id (Diakses 21 Agustus 2015 pada pukul 06.00 WIB dan 01 September 2015 pada pukul 05.53 WIB)

www.google.com 